\title{
Sufism in Writings: Mysticism and Spirituality in the Love Poems of Salleh Ben Joned
}

\author{
Nadiah Abdol Ghani \\ Faculty of Modern Languages and Communication \\ University Putra Malaysia
}

Received: 30-05- 2013

Accepted: 30-06- 2013

Published: 31-07- 2013

doi:10.7575/aiac.ijclts.v.1n.2p.33

URL: http://dx.doi.org/10.7575/aiac.ijclts.v.1n.2p.33

\begin{abstract}
Salleh Ben Joned is seen as a notorious figure in the Malaysian literary scene as a result of his use of profanities and vulgarities, interlacing them into ideas or texts that are seen to be sacred by the society. He is most infamously known for his vivid descriptions of carnal images and sex and its vicissitudes in his poems, thus earning the accusations of being an apostate and his works to be blasphemous. This essay is an attempt at reappraising his love poetry, by explicating the poems using the doctrine of Sufism and its central theme of love and the Beloved/Divine. My view is that his poems are not just describing the 'profane' act of sexual copulation, but rather would be more apt in describing a devotee's spiritual journey towards finding his Beloved or the Divine.
\end{abstract}

Keywords: Salleh Ben Joned, Sacred, Profane, Sufism, Poetry, Love

\section{Love Poetry of Salleh Ben Joned}

In contemporary studies of modern Malaysian literature, Salleh Ben Joned occupies a unique place in the literary imagination of the nation. The elusive writer with his swashbuckling style of writing has garnered himself avid fans and critiques alike with many references, commentaries and controversies contributing towards his infamous notoriety as a non-conventional poet. There are those oft-quoted statements from the late Usman Awang, A. Samad Said, Adibah Amin and Lat that has institutionalized the enfant terrible image of the poet ever since he first burst into the Malay literary scene in 1987 with his bilingual Poems Sacred and Profane - Sajak-sajak Salleh, followed by his second collection of poems Adam's Dream as well as his prose pieces, As I Please and Nothing is Sacred from his stint as a freelance writer for the News Straits Times (Nur Sheena Baharuddin, 2008, p.131).

His infamy came from his explicit use of graphic sexuality, profanity and challenging the absolutes in his poem and essays, all of which are seen as deliberate transgressions of religious, political and cultural boundaries that eventually resulted in the discomfiture of many Malay-Muslim readers $(\mathrm{Ng}, 2012, \mathrm{p} .1)$. Rather than treading lightly on those sensitive matters, Salleh Ben Joned instead chose to bulldoze his way to get his messages across and consequently readers are incensed by his blithe disrespect for totems and taboos (Adibah Amin, 1994, p.227). An example of one out of his many controversial writings is when he treated sacred scriptures as mutable fictions, daring to use sacred images in Islamic history, retelling it and lacing it with 'profane' carnal images. Aside from sex and its vicissitudes, he also has a penchant for portraying various historical events in Muslim history in his own mystical ways that would enrage orthodox Muslim readers. Inasmuch as readers may be offended by provocation of issues usually reserved as taboos and off-limits, it is made even worse with his swashbuckling style of writing, often described to be in an offensive tone, deliberate and satirical, cementing his symbol of national notoriety.

Despite Salleh Ben Joned having established himself as an important figure in the Malaysian literary world, his works were sadly under-reviewed due to its blasphemous and vulgar nature thus contributing the shallow pool of resources when it comes to this notorious writer who is an important facet in the canon of postcolonial Malaysian literature. To my knowledge, only a handful of critiques have published commentaries of his poetry, and those are Adibah Amin, whose critiques were included as an afterword in Salleh Ben Joned's As I Please and another as an introduction to Sajak-sajak Salleh / Poems Sacred and Profane. Another critique is Andrew Ng of Monash University who has two journals published in trying to explicate his poems and finally Nur Sheena Baharuddin of Universiti Islam Malaysia on Salleh Ben Joned's latest book, Adam's Dream.

From the limited analysis of his poetry pieces, critics like Adibah Amin, Andrew Ng and Noritah Omar addressed his use of the sacred and the profane, in which the intermingling of both is seen as an exploration of his Muslim identity as well as the use of profanities and vulgarities to incite a reaction from the Malay society. Although critics have detected the mysticism/spirituality and religious oeuvres that are latent and manifest in his poems, none has discussed it from the point of view of the doctrine of Sufism. Wong Phui Nam in his introduction to Salleh Ben Joned's second compilation of essays Nothing is Sacred mentioned him to be a writer who has more than a passing interest in and understanding of mystical Sufism (Wong, 2003, p.xiv). Following that lead, it is found that what he wrote were very much in line with the teachings of Sufism. It cannot be denied that the dichotomy of the sacred and profane has been defined and contested by numerous other religions in theological studies and that mysticism is not just confined to Islam but is 
believed by other world religions as well. Nevertheless, the fact that Salleh Ben Joned is writing from the perspective of a Malay-Muslim is the deciding factor behind the choice to analyze his works through the beliefs of Sufism.

Salleh Ben Joned has certainly has had his fair share of accusations of blasphemy and apostasy hurled his way as a result of him writing on religion, language and politics, more often than not infusing profanities and some would say 'vulgarities' of sex and its vicissitudes in sacred texts. This paper will analyze the most pressing issue of the matter, which is the use of sex and its symbols in sacred texts and thus this paper then aims to explicate his poems by tracing the influences of the teachings of Sufism, particularly related to his love poetry. First and foremost, a brief definition of Sufism will be given, followed by the symbolisms of Sufi poetry, which will then be used to analyze the love poems of Salleh Ben Joned.

Sufism is the name in which Islamic spirituality is always known, thus is generally known as the esoteric or inner dimension of Islam. The term 'sufi' in Islam is generally used to denote a mystic. William Chittick in his book Sufism defined 'Sufism' as always described as "mysticism", "esoterism" or "spirituality", usually with the adjective Islamic tacked on the front $(2000$, p.1). In addition, Syed Naguib al-Attas stated that the term sufi usually expresses what is meant by the term 'mystic' and tasawwuf expresses what is understood by the word 'mysticism' (1963, p.1).

Historians have commonly spoken of a gradual move or development of Sufism, one that begins in a mysticism of asceticism fear to one that would slowly emphasize on love and devotion and in turn stressing on knowledge and gnosis. Therefore, from about the thirteenth century onwards, love is one of the most important themes that had taken center stage in the teachings of the Sufis. This came about from the Hadith of the Hidden Treasure stating that god created people out of love for them. The most often cited Quranic proof text for this hierarchy of love is the verse, "He loves them, and they love Him" (5:54). Thus, first it started with God's love towards human beings and then human beings reciprocated that love towards God (Chittick, 2000, pp. 74-5). Here, the concept of the lover and the true beloved as well as the channels to achieve the union will be explained.

Salleh Ben Joned's poems of love served to highlight the feature of Sufi doctrine, love for the beautiful and the Beloved, a concept that the famed Sufi mystic and poet, Ibn Arabi was very much known for. In the words of Ibn Arabi:

The Prophet was quoted in an established hadith saying, "God is beautiful and He loves beauty". So He described Himself as loving beauty, and He loves the world, so there is nothing more beautiful than the world...It is God who made the world and endowed it with existence. The entire universe is therefore supremely beautiful. There is nothing ugly in it. On the contrary, in it God has brought together all perfections and all beauty...The gnostics see it as being nothing other than the form of divine Reality....for God is He who is epiphanized in every face. ${ }^{1}$

Therefore, this statement would constantly remind readers that love for any creature can only be love for God as their loves and desires externalizes God's love that is reflected in the creatures. These may include love towards a lover, father, mother, siblings, friends, heaven, earth, gardens, food and even drinks (Chittick, 2000, p.79-84).

As with most desires for the beloved and the exaltation of love, sex will definitely rise to importance. The very word 'sex' comes from the Latin root 'sexus' which would mean division, consequently carrying the meaning that sex divides. However, there is a great desire in man to be united and the act of man and woman joined in love is seen as an act of trying to create unity, hence the appeal of love and sex. Nevertheless, due to the divisive nature of sex, it will just create more desire for unity and more longing for the ultimate union. This revelation of sadness through love will become a revolution where the self will start moving to where the ego can be dissolved. Only when the ego is dissolved, a true teaching of Sufism, and only then can the self be led to God, thereby making Him man's Beloved with Divine union (Osho, 1977, pp. 60-2).

God's wisdom through His destiny and decree

made us lovers one of another

That foreordainment paired all the world's parts

and set each in love with its mate...

The female inclines towards the male

so that they may perfect the other's work.

God placed inclination in man and woman

so the world may subsist through their union. ${ }^{2}$

\footnotetext{
${ }^{1}$ qtd. in Alhaq, 1995, p.203

2 Mathnawi III 4400-1, 14-15;SPL 198-9, qtd. in Chittick, 2000, p.80
} 
In addition, the above statement by Mathnawi would bring us to the most remarkable and the most unorthodox themes in Sufis' work, in the coupling of the man and woman through sexual act. The pleasure that comes from sexual intercourse is a foretaste of the pleasures of Paradise, where, according to the Quran, chaste virgins will be at the service of believers; sexual pleasure here on earth induces men to serve God more in order to obtain those pleasures (4:108).

At the same time that sexual pleasures gained from the coupling of a man and a woman are seen as a foretaste of Paradise, women in general are still regarded as impure and merely to satisfy the physical drives of men. The Quran tells Muslim men that women are their fields, and they may go in their fields whenever they please (2:223). Arabi, the pioneer for love poetry stated that he too "...used to hate women and sex at the start of my entry into this path.:, a common wariness usually associated with the taboos of sexual desires. However, it was not until he contemplated Prophet Muhammad's hadith in which Muhammad says, "Three things have been made beloved to me in this world of yours: women, perfume, and prayer." This hadith then reinforced that there is nothing more beautiful in it in which the divine beauty is more perfectly revealed than the human female form. It is noted that Muhammad's love for women did not spring from his own nature, but from God who had made them beloved to Him. Hadith says that God made man in his own image, and just as man was made in the image of God, woman was made in the image of man (the Quran exegetes the story of Eve's creation from Adam's rib). That is why the Prophet said that God made women beloved to him and since the divine essence is transcendent and inaccessible, man can only see God as he is reflected in creation, and for man, there is no better way to contemplate God's love than in a woman (Hoffman-Ladd, 1992, p.85).

With the explanation of the symbolism of love poetry involving the concept of love and the Beloved, with sexual acts as a channel to achieve Divine union as well as a woman being the perfect mirror to contemplate God's love, the love poetry of Salleh Ben Joned can be explicated esoterically from its literal profane meanings. It is very apparent that Salleh Ben Joned is not shy in mixing the carnal and the divine in his poetry. This is the very reason why critiques are accusing him of blasphemy and as Muhammad Haji Salleh once said, "To Salleh, nothing is sacred", for they see him as irreverent enough to be mixing the sacred with the profane. Malaysia as an Islamic nation view sex and its vicissitudes as a taboo subject to be neither discussed nor written about openly. Being Malays and consciously Muslim, many critiques insist on holding on to Malay-Islamic values.

However, contrary to the taboo long held by the Muslim Malays on the topic of sex, Islam, unlike many other traditions, does not set out exclusive boundaries between the sexual and sacred spheres. Not only does Islam tolerate the sexuality of human beings, Islam also expressly addresses this issue since it is a religion that provides guidance to humans in terms of their social, physical and psychological attributes. This issue is addressed through the shari'a, Hadith and even the Qur'an itself, providing guidance on topics that would include creation, marriage and sexual etiquette (Machacek \& Vilcox (eds.), 2003, p.261)

In addition, classical Muslim scholars collected various details of Prophet Muhammad's life for reasons such as to worship his virtues, to record his words, actions and deeds to be a norm for believers and to provide a basis for Islamic law and custom. With this framework in mind, the sexual performance and intimate life of the Prophet that provided a rich account of his opinions and behaviors in regards to sex were frankly discussed in various Hadiths. These accounts designate Muhammad as a sexual being and that the Prophet is not beyond the desires and lures of sex. His sexual attraction to women was regarded as natural and appropriate as befitting of him being a human prophet (Ouzgane (ed.), 2006, p.57-9).

This explains the poem, Revelation of the Prophet that was published in Adam's Dream, a poem touching on the sexual act of Prophet Muhammad and his favourite wife, A'shah. The poem is accompanied with two hadiths, one of which is "...verily Revelation cometh not unto me when I am beneath the coverlet of a wife, except the wife be A'shah" (Prophet Muhammad according to the Hadith of Al-Bukhari qtd. in Ben Joned, 2007, p.23). The very act of orgasm that induced the Prophet to have a Revelation is described in these lines, "Suddenly, as he is in the frightening throes / Of one orgasm, he screams, "God is Great!" / A'ishah can only draw one conclusion. / The prophet is having a Revelation." (11-14).

Islam is a religion that looks at a sexual union between a man and a woman, husband and wife to be of a divine union. Hadiths say that God made man in his own image, and woman was made in the image of man. Thus, woman is from man, as man is from God, and just as God longs for man as a whole towards its part, the same would go for man who would long for woman. Thus Prophet Muhammad said, "His love is for his Lord in Whose image he is, this being so even as regards his love for his wife, since he loves her through God's love for him, after the divine manner." Hence, when a man loves a woman, he would desire sexual union with her as there is no greater union between the two sexes. Sexual union imitates God's relationship with man where the man is yearning for God who is his origin, and at the same time the woman yearns for her man. God made women dear to man, just as God loves that which is in His own image (qtd. in Hoffman-Ladd, 1992, p.88-9). By perceiving the spirit of God in woman, the sexual union itself, the joining of himself to her will make him aware of his oneness with God. According to Ibn al-'Arabi, in a sexual intercourse, the man is annihilated in the woman but this is in fact a type of annihilation to God. Indeed, should man engage in a sexual union in the realization of God in woman, the act itself is a means for the mystic's perfection. The annihilation will enable man to achieve the Sufi goal, fana', as the overwhelming pleasure found in the sexual intercourse perceiving the Divine in woman as a type of annihilation to God as it would remove him from any awareness of his own self.

The gnostic stated above would explain the Revelation that the Prophet was having during his sexual intercourse with his favourite wife, A'ishah. A Revelation is sent into this world from Beyond (Lings, 1975, p.33). The ecstasy he felt is 
the greatest pleasure given by God, who has created him in His image and created A'ishah from man, and the consummation of the sexual union completes the circle of man is to woman as God is to man. "Every time he comes his ecstasy seems / To her to shine in his eyes with a light / That's otherworldly." Here, the ecstasy directly mirrors the ecstatic experience, the annihilation of self and thus achieving union with God, an otherworldly experience sent from Beyond, thus making it a Revelation.

In the same poem, Salleh Ben Joned wrote of A'ishah wondering of a 'foretaste' of Paradise, "'Is this," she asks herself, "a sort of foretaste / Of the endless orgasms in Paradise?"”. In literal sense, the word foretaste means the pleasure that comes from the sexual intercourse is akin to the taste of pleasures of Paradise. However, the word 'foretaste' here may also denote the term much used by the Sufis following the Prophet to the directness of Heartknowledge as opposed to mind-knowledge. The Heart-knowledge must be consulted with the senses rather than the mind, and this is a key to the interpretation of many texts, amongst which are the Quranic descriptions of Paradise (Lings, 1975, p.52-5). Hence, the lines in the poem projected the meaning of the pleasures of the senses, as the act of sexual consummation becomes the earthly projections or shadows of the Paradisal archetypes. As stated above, sexual union annihilates oneself and consequently resulting in union with the Beloved and this is a significant aspect of Sufism, which is to achieve a state of human perfection, a perfection that would accord with the Earthly Paradise. Hence, reaching an orgasm is to reach to a state of perfection of Heart-knowledge, which would lead one to be in Paradise.

The same theme is explored in another of Salleh Ben Joned's poem, The Woman Who Said Yes, published in Poems Sacred in Profane. This poem too depicted the Prophet in a sexual intercourse, but this time with his first wife, Khatijah. The context of the poem fits the description reported in the Sahih of Bukhari depicting the time when Prophet Muhammad received his first revelation in the cave of Hira' on a mountain near Makka:

\author{
"Trembling with terror, he reached for her skirt; \\ the echo of the fierce voice in the cave \\ still thundered in the depths of his soul: \\ “...from a clot of blood...the Most Bountiful..."” (1-4)
}

The account of the whole experience was narrated by A'isha, the mother of the faithful believers in which an angel came to him in the cave and asked him to read and said: "Read, in the name of Your Lord, who created, created man from a clot. Read! And Your Lord is the most bountiful”... (Bukhari, I, No. 3; VI, No.478; Muslim I, No.301). The narration also went on to tell us that the Prophet went back to his wife Khatijah recounting his dreadful experience and she in turn comforting him to ease his fear by wrapping him in blankets (Mission Islam, n.d.).

\footnotetext{
““CCover me, Khatijah!” Devil or angel?

The sweat of terror drowned his certainty.

"Get inside me! And you'll know for sure."

He did - and terror burst into ecstasy." (9-12)
}

On a literal level, the poem would contain sexual innuendoes and the typical reader may feel outraged at the portrayal of the Prophet in the throes of passion especially right after receiving the first revelation. However, as explained earlier on, the act of sexual consummation is seen as a means of achieving ecstasy which would inherently lead to the annihilation of self, thus achieving union with the Beloved, akin to receiving a revelation. The line "Get inside me!" connotes penetration and according to Sufic interpretation, this would mean the unlocking of the 'Gates of Heaven' on the night of Revelation, and thus the penetration in question would mean the penetration of the natural by the supernatural (Lings, 1075, p.92).

What is more, it is the 'journey' of the Prophet here from terror to ecstasy that we would want to pay attention to. The terror is him being afraid of God, similar to the concept of 'Godfearing' people which Sufis deem as absurd. We have been taught to be afraid of God, fear of hell, fear of punishment and the resulting piety is based on the virtue of fear. In contrast, Sufis believe that love will never be the result of fear and therefore it is not possible for man to love God if the fundamental belief that has been held on to was the initial fear to God. The result of fear-oriented mind will likely be tolerance, and worse, hate in which man sill strive to kill God, or the concept of God. That was what Nietszche did when he declared "God is dead and now man is free". This is a phenomenon that is apparent in these days as the fear in a Godfearing person will render him unable to move into the deeper realms of religion, failing to be free with God and failing to create a relationship with God. In contrast, Sufis are Godloving people. This would mean that they want to know God, and they are in search of God for when they love God, they want to face Him and they want to see Him (Osho, 1977, p.4). 
Therefore, the Prophet's journey or rather his feelings from one of "terror", or fear of God has then changed to "ecstasy" in which he revelled in the first of many revelations bestowed upon him. Here, the concept of love leading to "ecstasy" will be explained. According to Nicholson:

There are really two kinds of contemplation. The former is the result of perfect faith, the latter of rapturous love, for in the rapture of love, a man attains to such a degree that his whole being is absorbed in the thought of his Beloved and he sees nothing else. ${ }^{3}$ (p.55).

Aside from poetry depicting the sexual union of the Prophet, Salleh Ben Joned too has written love poetry imbued with sexual imageries between common men and women as depicted in several of his other poems namely Infidel Wife, $A$ Hymn to My Sarong, The Selendang of Death and I and various other poems in his two collections of poetry. Nevertheless, it is important to note that he would write of sexual union with the persona's legitimately married spouse and not with random partners or in an adulterous relationships. This is imperative to ensure that sexual union is still seen as sacred and not an act that can be dallied with freely. For example, in "A Hymn to My Sarong";

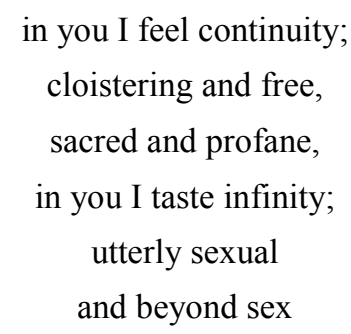

These lines would suggest the sexual act is not just constricted to the profane act of sex, but would suggest something far beyond that that is sacred and infinite. Lines further in the poem would reflect echoes of Sufi doctrine of absolute love;

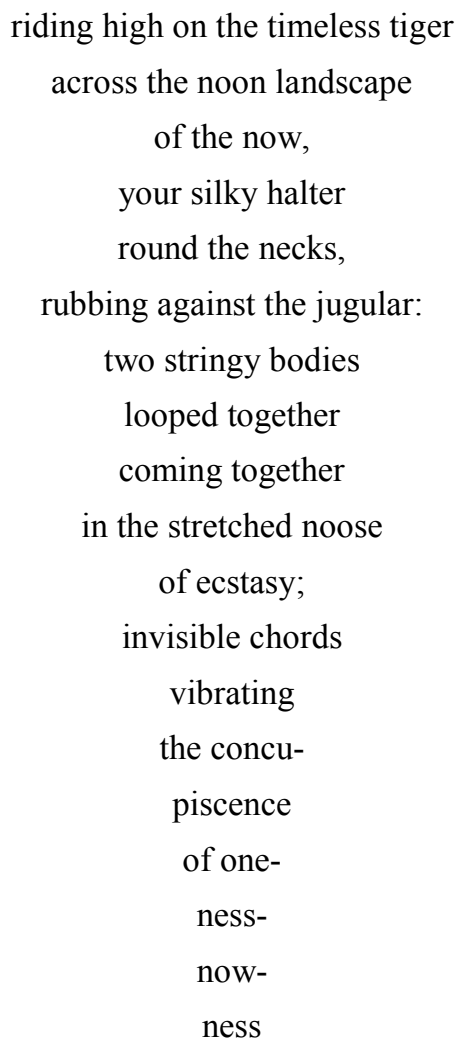

The poem is typical of many Sufi poems that are often described through erotic imagery of absolute love between man and woman. Here, love produces a mystic oblivion of time as described from the lines "timeless tiger" and "now- / ness". This poem also reflected the experience of death in love, as depicted from the lines, "in the stretched noose / of ecstasy" in that the lovers overcome even the fear of death in order to reach ecstasy, in that is the intoxication from the

\footnotetext{
${ }^{3}$ Nicholson, Mystics of Islam, 1963, p.55 qtd. In Samah Selim, 1992, p.31
} 
annihilation of the self to reach the transcendent. The total oblivion brought God close to them, as close as He can be a "the jugular vein". Thus, love is a means of understanding and illumination to achieve Divine Union and can be ultimately seen from the line "of one- / ness".

\title{
2. Conclusion
}

Salleh Ben Joned has certainly been side-lined by the Malay literati world for his notoriety in the tainting of the sacred with the use of profanities and vulgarities. Nevertheless, the explication of his love poems above would justify that he is a poet informed by Sufism and has thus penned his poetry and thoughts with the influence of the branch of Islamic mysticism. Therefore, instead of being plain irreverent and a joker without a cause as stipulated, Salleh Ben Joned has proven that his is not blatant blasphemy and he has provided scriptural authority to defend his cause. Nevertheless, it is important to note that most Sufi mystics have been labelled as apostates and accused of heresy in their time, some of which had been tried and prosecuted in following the Sufi path. Therefore, it is of no surprise that Salleh Ben Joned is on the receiving end of similar accusations today despite him writing in this day and age when modernization is fast enveloping the society of today.

Despite the proof given, no doubt critics would still be wary of his use of profanities, especially when it comes to texts or ideas that are seen sacred to Muslims. Andrew Ng in his commentary of Salleh Ben Joned's poems also voiced this thought in which he pondered on the extent of the use of the carnal images to evoke a response from readers and whether it is even necessary to go to the length that Salleh Ben Joned has gone to just to prove his point. In light of these thoughts, Nicholson attributed this to the 'symbolic style' of Sufic poetry in which it serves a double function:

\begin{abstract}
It has been said that the Sufis invented this figurative style as a mask for mysteries which they desired to keep secret. That desire was natural in those who proudly claimed to possess an esoteric doctrine known only to themselves; moreover, a plain statement of what they believed might have endangered their liberties, if not their lives. But apart from any such motives, the Sufis adopt the symbolic style because there is no other way of interpreting mystical experience. So little does knowledge of the infinite revealed in ecstatic vision need an artificial disguise that it cannot be communicated at all except through types and emblems drawn from the sensible world, which, imperfect as they are, may suggest and shadow forth a deeper meaning than appears on the surface. ${ }^{4}$
\end{abstract}

Hence, Salleh Ben Joned's use of carnal images may not have necessarily been aimed purely at evoking a response from readers, nor were they conjured to be rebellious or different from other writers. Instead, they were his honest exploration of spirituality and mysticism and the divine experience cannot be explained in other terms except for those that he has utilized in his poems. This quest towards his spiritual journey, together with Salleh Ben Joned's free spirit and bravery have made him into the iconic, if not notorious figure in the literary world that he is today. However, it is without a doubt that his poems are not for the faint-hearted, yet, it is hoped that by reframing him in this new Sufic light will at least allow readers to attempt to understand the latent and the manifest within his poetry pieces before jumping into premature conclusions.

\section{References}

al-Attas, S. N. (1963). Some aspects of Sufism as understood and practised among the Malays. Singapore: Malaya Publishing House LTD.

Alhaq, S. (1995). A Forgotten Vision: A study of human spirituality in the light of the Islamic tradition. Selangor: Thinker's Library Sdn. Bhd.

Amin, A. (1987). Rising Above the Barriers: Review of Sajak-sajak Salleh: Poems Sacred and Profane. New Straits Times.

Amin, A. (1994). Afterword. In S. B. Joned, As I Please (pp. 227-229). Singapore: Skoob Books.

Baharuddin, N. S. (2008). Review of Adam's Dream by Salleh Ben Joned. Asiatic, 2(2), 131-133.

Chittick, W. C. (2000). Sufism: A Beginner's Guide. Oxford: Oneworld.

Hassan, M. (2007). Sufism and English Literature, Chaucer to the Present Age: Echoes and Images. New Delhi: Adam Publishers.

Hoffman-Ladd, V. J. (1992). Mysticism and Sexuality in Sufi Thought and Life. Mystics Quarterly, 18(3), 82-93.

Joned, S. B. (1994). As I Please. Singapore: Skoob Books.

Joned, S. B. (2003). Nothing is Sacred. Selangor: Maya Press.

Joned, S. B. (2008). Poems Sacred and Profane 3rd edn. Selangor: Silverfish Books.

Lings, M. (1975). What is Sufism. Cambridge: The Islamic Texts Society.

Machacek, D., \& Wilcox, M. (2003). Sexuality and the World's Religions. United States: Library of Congress.

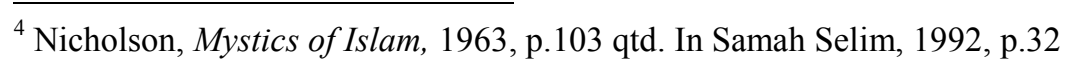


Mojaddedi, J. A. (2003). Getting Drunk with Abu Yazid or Staying Sober with Junayd: The Creation of a Popular Typology of Sufism. Bulletin of the School of Oriental and African Studies, University of London, 66(1), 1-13.

Ng, A. (2012). The Sacred Profane in the Poetry of Salleh Ben Joned. Kajian Malaysia, 30(1), 1-21.

Osho. (1977). Talks on Sufism. Sufis: The People of the Path Vol. 1, 1-284.

Ouzgane, L. (. (2006). Islamic Masculinities. New York: St. Martin Press.

Selim, S. (1990). Mansur al-Hallaj and the Poetry of Ecstasy. Journal of Arabic Literature, 21(1), 26-42.

Windstedt, R. (2007). Shaman Saiva and Sufi. London: BiblioBazaar.

Wong, P. N. (2003). Introduction. In S. B. Joned, Nothing is Sacred. Selangor: Maya Press. 